\title{
THE Y CHROMOSOME OF DROSOPHILA PSEUDOOBSCURA
}

\author{
TH. DOBZHANSKY \\ California Institute of Technology, Pasadena, California \\ Received January 10, 1935 \\ INTRODUCTION
}

The variation in the shape of the $\mathrm{Y}$ chromosome of Drosophila pseudoobscura Frolowa was first observed by LANCEFIELd (1929). He found that race $\mathrm{A}$ of this species has a $\mathrm{J}$-shaped, and race $\mathrm{B}$ a $\mathrm{V}$-shaped $\mathrm{Y}$ chromosome. This difference in the shape of the $\mathrm{Y}$ chromosome remains the only known "morphological" differential between the two races of this species, which are otherwise distinguished by their behavior in crosses (LANCEFIELD, l. c.), and by a number of physiological characteristics (Poulson 1934, Dobzhansky 1935, Boche unpublished). Dobzhansky and Boche (1933) observed that the shape of the $\mathrm{Y}$ chromosome does not remain constant even within a race; two types of $\mathrm{Y}$ chromosomes occur in race $\mathrm{A}$, and two other types in race B. Further studies, to be reported in the present paper, have increased the number of the types of $\mathrm{Y}$ chromosomes known in the species up to at least six, and shown that each of these types occurs in populations inhabiting a distinct geographic area.

\section{MATERIAL AND METHODS}

Wild strains of Drosophila pseudoobscura were collected, as far as possible, throughout the specific range. Flies were captured in traps containing fermenting banana mush; traps were exposed on trees and bushes, preferably far from human habitations (because of the possibility that flies are transported from place to place by man). Flies come into the traps, frequently in great numbers, especially during the evening hours. Usually more than one strain was isolated from each of the populations thus obtained. Each strain was derived from a single female fertilized in nature by one or more males. The strains were designated by the names of the localities in which their wild ancestors had been collected, and by serial numbers. Thus, "Seattle-6" is the strain No. 6 from Seattle, Washington.

The writer wishes to acknowledge his obligations to Miss C. V. BEERs, Miss M. Groscurth and Messrs. R. D. Boche, V. M. Emmel, M. M. LerNer, D. F. Poulson, C. N. Rudkin, A. H. Sturtevant, and R. C. WarNER who collected a part of the material.

The shape of the $\mathrm{Y}$ chromosome was determined by examining the spermatogonial metaphase plates. In Drosophila pseudoobscura the spermatogonial divisions are numerous enough in the testes of the adult males to permit a determination of the chromosome group in practically every specimen. Most of the material was studied in aceto-carmine smear 
preparations, and the remainder in sections fixed in Flemming's or Benda's fluids and stained with iron haematoxylin. Five or more chromosome plates were examined before the kind of the $\mathrm{Y}$ chromosome present in a given strain was considered established. This was necessary because the differences between some of the types of $\mathrm{Y}$ chromosome (types I and III, and types IV and V, see below) are relatively small.

The cytological examination was performed as a rule several fly generations after the strains were brought to the laboratory. In no case was more than one type of the $\mathrm{Y}$ chromosome observed in a single strain (this possibility could not be excluded a priori, since some of the original females might have been fertilized in nature by several males possessing $\mathrm{Y}$ chromosomes of different types).

\section{CXTOLOGICAL CHARACTERISTICS OF THE TYPES OF Y CHROMOSOME}

The Y chromosome of Drosophila pseudoobscura may have a median, submedian, or subterminal spindle fibre attachment. The two limbs of the chromosome vary in their absolute and relative lengths; these variations permit the identification of the following six types of $\mathrm{Y}$ chromosomes (a number of figures showing the types I, II, IV and V have been published in Dobzhansky and Boche 1933, Dobzhansky 1934 and Darlington 1934. In Doвzhansky and Boche's paper type IV was referred to as the "third type", and type V- " the fourth type").

Type I (figures 1 and 2). The $\mathrm{Y}$ chromosome is $\mathrm{V}$-shaped, the spindle attachment is submedian. The length of the long limb of the $Y$ is approximately equal to that of either limb of the $\mathrm{X}$ chromosome. The ratio of the lengths of the two limbs of the $\mathrm{Y}$ is about $6: 4$ or $6: 4 \frac{1}{2}$. The long limb frequently shows a constriction or a bend somewhat distally from the middle of its length.

Type II (figures 3-6). A V-shaped chromosome with a more nearly median spindle attachment than in type $\mathrm{I}$. The ratio of the two limbs is $3: 4$ or $3 \frac{1}{2}: 4$. The longer limb is clearly shorter than either limb of the $X$. No constrictions are visible in either arm. Type II can be derived from type I by a loss of the distal portion of the long limb of the type I, from the constriction to the end. On this supposition, the longer limb in type II is homologous to the shorter limb in type I, and the shorter limb in type II is a homolog of a part of the longer limb in type I.

Type III (figures 7-9). A markedly unequal armed, V-shaped chromosome. The ratio of the two limbs is approximately $6: 3$ or $6: 2 \frac{1}{2}$. This type can be derived from type I by a loss of a portion of the shorter limb.

Type IV (figures 10 and 11). A J-shaped chromosome with a subterminal spindle attachment. The length of the longer limb approaches that of either limb of the $\mathrm{X}$ chromosome, and is greater than that of the 
longest autosome (figure 11 is rather exceptional in this respect). The longer limb sometimes shows a constriction at about the middle of its length.

Type $V$ (figures 12-14). This type can be derived from the type IV by a loss of a portion of the longer limb. The longer limb in type $\mathrm{V}$ is about as long as the shortest rod-shaped autosome.

Type VI (figures 15-20). A relatively very short chromosome with a nearly median spindle attachment. The length of either arm is clearly

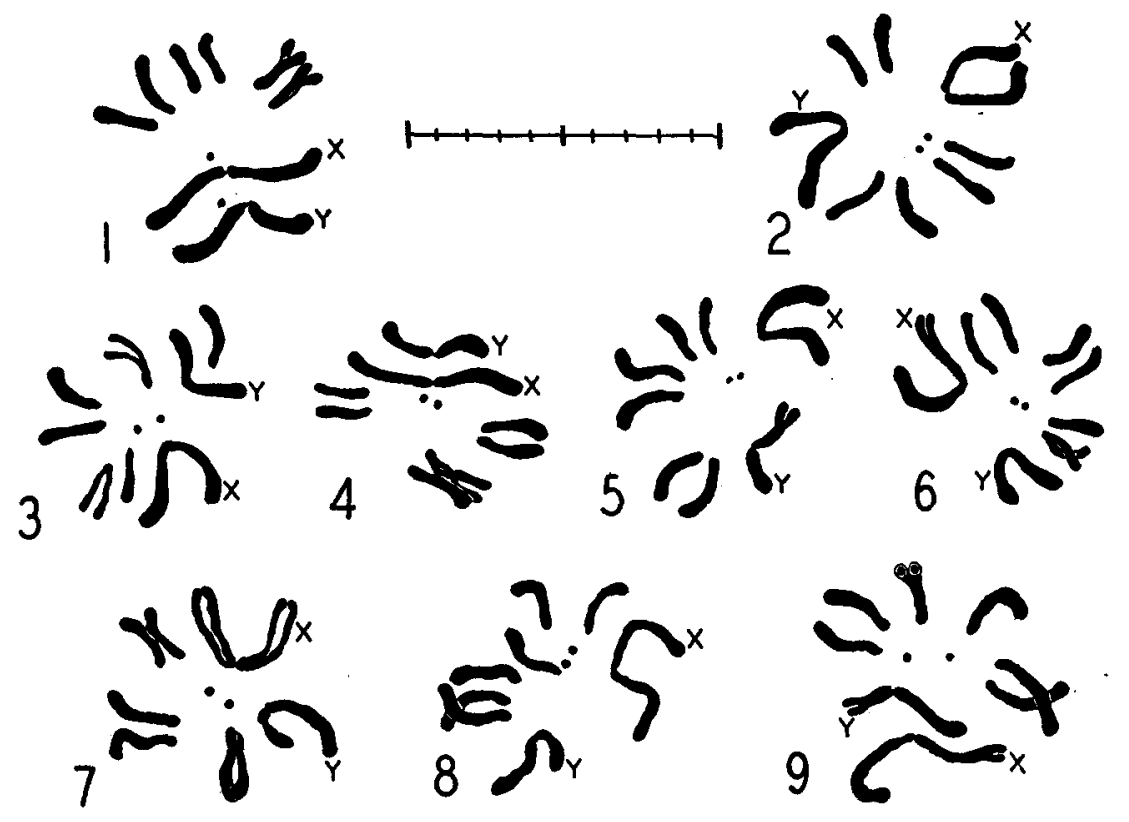

Figures 1-9.-Chromosomes of race B of Drosophila pseudoobscura. Figures 1 and 2-type I (Lassen-7); Figures 3-6-type II (Seattle-4); Figures 7-9-type III (Sequoia-5). The scale $\left(10_{\mu}\right)$ is common to figures $1-20$.

smaller than that of the shortest rod-shaped autosome. The derivation of this type is not quite clear. It might conceivably arise from type $\mathrm{V}$ by an inversion transposing the spindle attachment from the subterminal to the median position.

The strains of Drosophila pseudoobscura are classified as to race on the basis of genetic tests: the cross $\mathrm{B}+\times \mathrm{Ao}$ gives sterile $\mathrm{F}_{1}$ males having testes much smaller than normal in size, and the $F_{1}$ hybrid males from the cross A $q \times B \sigma^{\top}$ are sterile but have normal sized testes (LANCEFIEID 1929). Such tests were performed on all the strains in which the shape of the $\mathrm{Y}$ chromosome was determined. The results show that Y chromosomes of the types IV, V and VI occur exclusively in males of A race. Similarly, the types I and II are found in race B only. Type III was observed in several 
$\mathrm{B}$ race strains, and in a single A race strain (Sequoia Park-7). The latter case deserves some consideration, since it is difficult to see how a $\mathrm{Y}$ chromosome of race $\mathrm{B}$ could be transferred into race $\mathrm{A}$, or vice versa. Three possibilities can be suggested: (1) type III is the ancestral type of $\mathrm{Y}$ chromosome that has been retained only in some race B strains and in a single known race A strain; (2) non-disjunction of the sex chromosomes in an interracial hybrid resulted in an appearance of an XXY female, and a fertile male carrying the $\mathrm{X}$ chromosome of one race and the $\mathrm{Y}$ of the other emerged in its offspring; (3) the $Y$ chromosome of the Sequoia-7
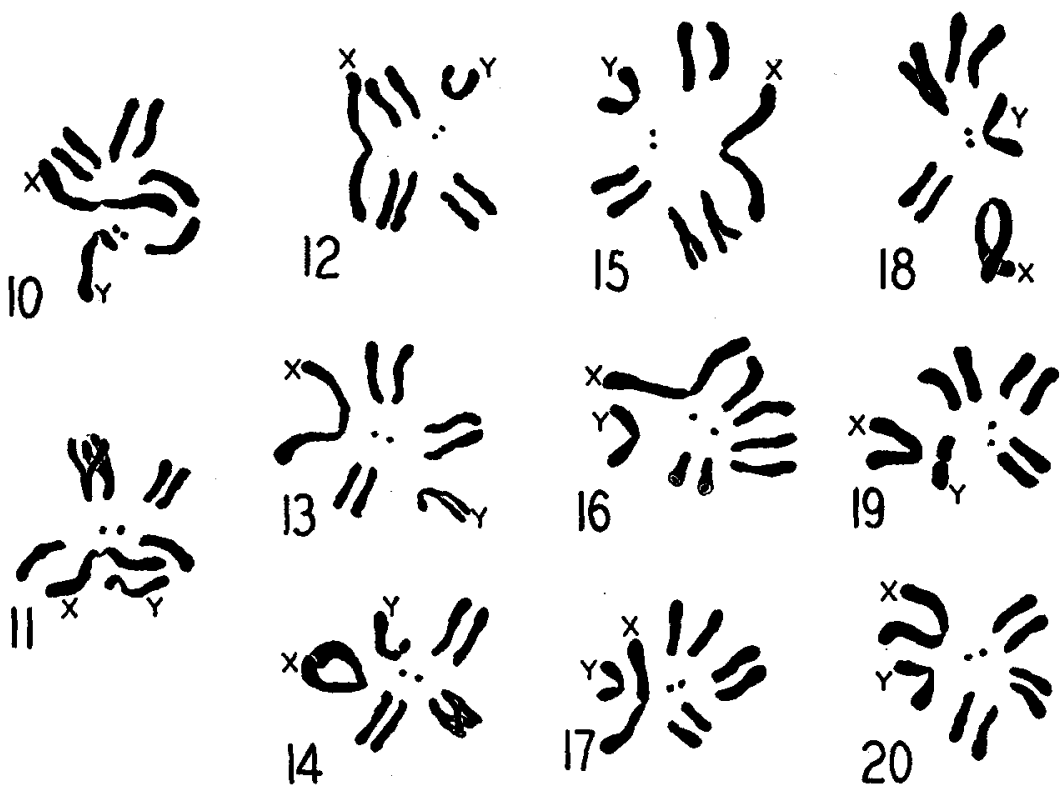

FIGUREs 10-20.-Chromosomes of race A. Figures 10 and 11-type IV (Merritt-2); Figures 12-14-type V (The Dalles-5); Figures 15-20-type VI (Cedar City).

strain belongs to a separate type which is merely superficially similar to the type III. The third possibility seems most plausible. If this were established, the number of the known types of $\mathrm{Y}$ chromosomes in the species Drosophila pseudoobscura would be actually seven rather than six.

\section{GEOGRAPHIC DISTRIBUTION OF THE DIFFERENT TYPES OF Y CHROMOSOME}

The strains that were examined for the type of $\mathrm{Y}$ chromosome are listed below. The number of chromosome plates observed for this purpose is given in brackets after the name of each strain. Thus, "Vancouver-1 (10)" indicates that ten metaphase plates have been inspected in the strain No. 1 from Vancouver, British Columbia. 


\section{Type I (Race B)}

Vancouver Island: Cowichan Lake-2 (7).

British Columbia: Vancouver-3 (5), Yale-5 (5), Yale-6 (5), Merritt-3 (11), Merritt-4 (3), 150-mile House-5 (5), Quesnel-5 (5).

Washington: Cape Flattery-8 (11), Olympic Mts.-3 (8), Olympic Mts.-5 (7), Olympic Mts.-6 (8), Seattle-2 (12), Seattle-6 (21), LaGrande-4 (10), Chehalis-3 (7).

Oregon: Newport-5 (18), Reedsport-3 (7), Days Creek-2 (6), Crater Lake-4 (8), Sisters-9 (9).

California: Klamath-5 (6) Shelter Cove-1 (3), Shelter Cove-6 (7), Mendocino-1 (18), Dunsmuir-1 (10), Dunsmuir-2 (9), Lassen-4 (5), Lassen-7 (5), Mammoth Lake-1 (9), Sequoia Park-10 (9), Sequoia-8 (18), Greenhorn Mts.-6 (9), Greenhorn Mts.-8 (7), Santa Lucia-11 (9).

\section{Type II (Race B)}

Vancouver Island: Campbell River-1 (8), Campbell River-3 (10), Campbell River-4 (9), Cowichan Lake-6 (4).

British Columbia: Vancouver-1 (10), Yale-3 (9).

Washington: Cape Flattery-1 (10), Cape Flattery-3 (6), Cape Flattery-7 (5), Olympic Mts.-4 (9), Seattle-4 (23).

\section{Type III (Race B)}

California: Mammoth Lake-10 (12), Sequoia Park-4 (7), Sequoia Park5 (6), Greenhorn Mts.-3 (10), Kern Canyon-7 (6), Santa Lucia-6 (7), Nojogui-3 (8), Nojogui-8 (8)

\section{Type III (?) (Race A)}

California: Sequoia Park-7 (18).

\section{Type IV (Race A)}

British Columbia: Yale-5 (7), Pavilion-3 (12), Pavilion-5 (8), Kamloops-2 (9), Merritt-2 (5), Lake Okanagan-1 (9).

Washington: Olympic Mts.-2 (14), Seattle-1 (9), Seattle-5 (14), LaGrande-2 (14), Chehalis-6 (5), Lake Chelan-1 (6), Lake Chelan-2 (5), NE of The Dalles-6 (8).

Oregon: Sisters-4 (7), Paulina Lake-3 (9), Crater Lake-3 (14).

California: Dunsmuir-4 (8), Lassens-1 (6), Mammoth Lake-2 (5), Mammoth Lake-8 (F 10), Greenhorn Mts.-2 (5), Greenhorn-4 (6), Greenhorn-5 (5), Greenhorn-10 (5), Greenhorn-11 (5), Greenhorn-12 (5), Kern Canyon-1 (6), Kern-2 (5), Kern-3 (5), Kern-4 (8), Kern-5 (5), Santa Lucia-1 (4), Santa Lucia-2 (6), Santa Lucia-5 (5), Santa Lucia-8 (5), Santa Lucia10 (8), Nojogui-2 (7), Nojogui-4 (5), Nojogui-7 (6), Pasadena-1 (4), Pasadena-2 (7), Pasadena-3 (5), Pasadena-4 (5), San Bernardino Mts.-3 (5), Henshaw Lake-1 (17). 


\section{Type V (Race A)}

British Columbia: Lake Okangan-2 (8), Shuswap Lake-1 (5), Shuswap Lake-3 (9), Arrowhead-5 (5), Nakusp-2 (9), Nakusp-3 (9), Kaslo-3 (13). Washington: The Dalles-5 (5), Metaline Falls-4 (8).

Idaho: Lake Coeur d'Alene-6 (5), Idaho Falls (10).

Montana: Bitterroot Mts.-1 (6), Bitterroot Mts.-2 (9).

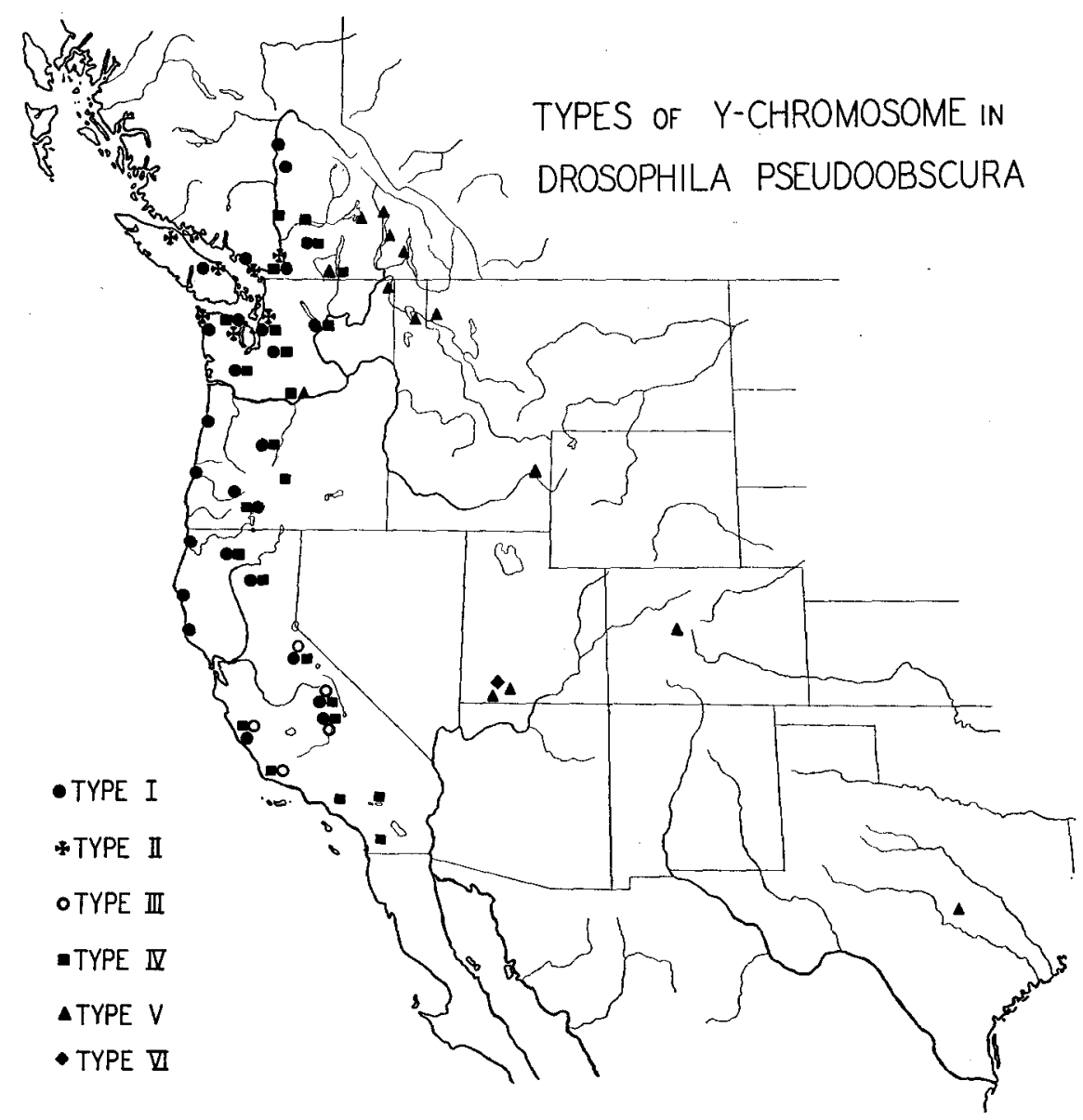

FIGURE 21.-The known geographic distribution of the types of the $Y$ chromosome.

Colorado: Aspen-1 (11), Aspen-2 (6).

Utah: Bryce (9), Zion-1 (10).

Texas: Georgetown (13).

Utah: Cedar City (24).

Type VI (Race A)

The above data are summarized in figure 21 in map form. It may be regarded as established that each type of $\mathrm{Y}$ chromosome has a definite 
geographic distribution, albeit in a number of localities more than one type is encountered in the population. Type $I$ is found almost everywhere within the area of race B. Type II is restricted to the region around Puget Sound. Type III is endemic in the Sierra Nevada and the southern Coast Ranges. Western representatives or race $\mathrm{A}$ have the $\mathrm{Y}$ chromosome of type IV, and eastern ones of type V. Types IV and V are encountered together only in a relatively narrow stretch in British Columbia and on the lower Columbia River. Type VI is known thus far from a single locality in southern Utah. Since, however, the characteristics of the population inhabiting Arizona and New Mexico are as yet unknown (the species pseudoobscura does occur at least in Arizona, and probably in New Mexico and in northern Mexico), the distribution of type VI may be much wider that it appears at present.

\section{INDEPENDENCE OF THE GENETIC CHARACTERISTICS FROM}

THE TYPE OF THE Y CHROMOSOME

A number of attempts were made to find a correlation between the type of the $\mathrm{Y}$ chromosome present in a given strain and some other properties of that strain. Thus far these attempts have been unsuccessful

Hybrids between strains of the same race having different types of $\mathrm{Y}$ chromosome are fertile in both sexes. The $F_{1}$ hybrid males from the interracial crosses are, of course, sterile, but there exist valid reasons for doubting whether this sterility has anything to do with the $\mathrm{Y}$ chromosome (DoBzhaNsky 1933). Originally it was deemed probable that the type of the Y chromosome determines, at least partly, the "strength" of a given strain. The "strength" of a strain is measured by the degree of the disturbance of the spermatogenesis observed in the hybrids between that strain and a standard strain of the other race (DobzhANSKy and Boche 1933, Doвzhansky 1934). The information now available shows this correlation to be spurious. Indeed, the strains "Texas" and "Shuswap-3" have the same type of $\mathrm{Y}$ chromosome, but the former is the strongest and the latter is the weakest A race strain known. Shuswap-3 and Chelan-2 are both very weak A race strains, but they have different types of $\mathrm{Y}$ chromosomes. Similar information is available for race B. As shown above, each type of $\mathrm{Y}$ chromosome occurs in a definite geographic region; variations in strength likewise involve a geographic element (unpublished data). These variables are, however, independent. The unpublished data of StURTEvan' on the geographic distribution of autosomal inverted sections and of the so-called sex-ratio factors also indicate no correlation with the type of the $\mathrm{Y}$ chromosome.

The lack of influence of the type of the $\mathrm{Y}$ chromosome on the genetic properties of the strain carrying it is not altogether unexpected. The $\mathbf{Y}$ 
chromosomes of Drosophila melanogaster and simulans are known to be practically devoid of genetic factors. It is almost certain that the $\mathrm{Y}$ of pseudoobscura is likewise inert (the XO males are not visibly abnormal though they are sterile, and the $\mathrm{Y}$ chromosome is invisible in the cells of the larval salivary glands). It is just this peculiarity of the $\mathrm{Y}$ as compared with the rest of the chromosomes that makes the former especially liable to undergo far reaching alterations without endangering the life of the organism. It should be pointed out in this connection that racial variability of the $\mathrm{Y}$ chromosome within a species is observed not only in Drosophila pseudoobscura but also in Drosophila simulans (STURTEvant 1929 and Heitz 1933) and in Drosophila caribbea (KaufmanN, personal communication). The well-known results obtained by STERN in Drosophila melanogaster are also a case in point.

Our inability to detect any influence of the variations in the $\mathrm{Y}$ chromosome on the morphological or physiological characteristics of its carrier does not constitute a conclusive proof of the non-existence of such influences. Nothing is known about the mechanism of the origin of the racial variations in the $\mathrm{Y}$ chromosome, nor do we know anything about the way these variations become established in nature. A number of interesting problems confront us in this field.

\section{DISCUSSION}

In accordance with the data presented above, the species Drosophila pseudoobscura might be subdivided into at least six races having different shapes of the $\mathrm{Y}$ chromosome and different geographic distributions. A review of the literature, even excluding cases of polyploidy and of abnormalities observed in single individuals, shows that chromosomal variations within a species are not uncommon. The first thoroughly established instance of this nature is that of Galtonia candicans (S. NAvashIN 1912, 1927). Two kinds of individuals are found in this plant: some have two large satellites on a certain pair of chromosomes, and others have one chromosome with a large and one with a small satellite. The biotype having two small satellites is inviable.

Races having different chromosome numbers are known in the moth Phragmatobia fuliginosa (SEILER 1917, 1925), the Orthopteron Gryllotalpa vulgaris (PAYNe 1916, VoINov 1925, DE WINIwARTER 1927), in Viola kitaibeliana (Clausen 1927), in flax, Linum usitatissimum (Емme and SchePelJEVA 1927), in Ranunculus acris (SoROKIN 1927), and in Scirpus palustris (HÅKANSSON 1929). The classical example of variations in the chromosome number within a species described by WILsON (1909) in Metapodius seems to belong to a different category from the above, and is probably related to cases of the rather mysterious "extra chromosomes" 
found more recently by Kuwada, Randolph and McClintock in Zea mays (Avdulov 1933), by Gotor in rye (Lewitsky, Melnikov and Titova 1932), and by Avdulov and Titova (1933) in Paspalum stoloniferum. The "extra chromosomes" represent either multiplications of one of the chromosomes of the normal set ( $Y$ chromosome in Metapodius), or, as in cases of Zea and rye, they are elements finding no homologs among the normal chromosomes, and appear to be composed of inert or semi-inert material. The chromosomal variations observed by SEILER (1922a, b) in Solenobia pineti and triquetrella, by DEDERER (1928) in Philosamia cynthia, and by Thomsen (1927) in Aleurodes proletella may belong to either category.

Racial differences in the visible chromosome morphology have been established in Galtonia (NAVAshiN, 1.c.), in some species of grasshoppers (Carothers 1917, Helwig 1929, 1933, King 1923), in Beta vulgaris (Kuzmina 1927), and in Vicia angustifolia (Sweschnikowa 1928, 1929). Amongst the examples just quoted those of Phragmatobia, Gryllotalpa, and the grasshoppers are especially interesting since these "chromosomal races" seem to have definite geographic distributions.

Differences in the internal structure of the chromosomes are no less important than those in the visible morphology or in chromosome numbers. Rearrangements of the "normal" order of genes within the chromosomes are known to occur in nature in Datura (BLAKESLEE 1929) and in Drosophila melanogaster, simulans and pseudoobscura (StURTEVANT 1931, LanCEField 1929, unpublished data of Sturtevant and TaN). Ring configurations observed at meiosis in interracial hybrids indicate that the parental races differ in having translocations. Such configurations are known in Oenothera, Datura, Pisum, Tradescantia, Rosa, Campanula, Aucuba, and other plants. Configurations described by Heberer in races of the Copepod Diaptomus castor (1924) are best interpreted as being due to translocations. Differences in the chromosome numbers (except polyploidy) and in the visible chromosome morphology imply, in fact, the existence of internal reconstructions in the chromosomal apparatus.

All these data indicate that the process of race and species formation may be resolved into at least two components: the genic differentiation and the differentiation in the chromosome structure. These two components seem virtually independent, but the phenomena of position effects may lead us to a recognition of an ultimate connection between the two. It should, however, be emphasized that the differences between races and species may be in some cases predominantly genic, and in others predominantly chromosomal in nature. The probable dual nature of the phenomenon of hybrid sterility (Dobzhansky 1934) indicates that, in its generalized form, the problem of race and species formation is reduced to 
that of the origin of dynamic discontinuities of the living matter, rather than to that of the origin of one or the other class of specific differences.

\section{SUMMARY}

1. The Y chromosome of Drosophila pseudoobscura may have a median, submedian, or subterminal spindle fibre attachment. The absolute and relative lengths of the two limbs of the chromosome vary, giving rise to six cytologically recognizable types of the $\mathrm{Y}$ chromosome.

2. Three of the six types are encountered only in race $A$ of the species, two others only in race $B$, and one type is found in several $B$ race strains and in a single $A$ race strain from the same locality.

3. Each of the six types occurs in wild populations inhabiting a definite geographic area (figure 21).

4. The morphological and physiological properties of a given strain are apparently not affected by the type of the $\mathrm{Y}$ chromosome present in that strain.

\section{LITERATURE CITED}

Avdulov, N., 1933 On the additional chromosomes in maize. Bull. Appl. Bot., Genet., Pl. Br., 2: $101-130$.

Avdulov, N. and Trtova, N., 1933 Additional chromosomes in Paspalum stoloniferum Bosco. Bull. Appl. Bot., Genet., Pl. Br., 2: 165-172.

Blakeslee, A. F., 1929 Cryptic types in Datura due to chromosomal interchange, and their geographical distribution. J. Hered. 20: 177-190.

CARoThERS, E. E., 1917 The segregation and recombination of homologous chromosomes found in two genera of Acrididae (Orthoptera). J. Morph. 28: 445-521.

Clausen, J., 1927 Chromosome number and the relationship of species in the genus Viola. Ann. Bot. $41: 677-714$.

DarLIngton, C. D., 1934 Anomalous chromosome pairing in the male Drosophila pseudo-obscura. Genetics 19: 95-118.

Dederer, P. H., 1928 Variations in chromosome numbers in the spermatogenesis of Philosamia cynthia. J. Morph. Physiol. 45: 599-613.

Dobzhansky, Th., 1933 Role of the autosomes in the Drosophila pseudoobscura hybrids. Proc. Nat. Acad. Sci. Washington 19: 950-953.

1934 Studies on hybrid sterility. I. Spermatogenesis in pure and hybrid Drosophila pseudoobscura. Z. Zellf. mik. Anat. 21: 169-223.

1935 Fecundity in Drosophila pseudoobscura at different temperatures. J. Exp. Zool. (in press).

Dobzhansky, Th. and Boche, R. D., 1933 Intersterile races of Drosophila pseudoobscura Frol. Biol. Zbl. 53: 314-330.

EMme, H. and SchepeljeVA, H. 1927 Versuch einer karyologischen Analyse von Linum usitatisimum L. Bull. Appl. Bot., Genet., Pl. Br. 17: 265-272.

HÅkansson, A., 1929 Über verschiedene Chromosomenzahlen in Scirpus palustris L. Hereditas 13: $53-60$.

Heberer, G., 1924 Die Spermatogenese der Copepoden. I. Die Spermatogenese der Centropagiden nebst Anhang über die Oogenese von Diaptomus castor. Zeit. wiss. Zool. 123: 555646.

HeItz, E., 1933 Die somatische Heteropyknose bei Drosophila melanogaster und ihre genetische Bedeutung. Z. Zellf. mik. Anat. 20: 237-287. 
HeLwig, E. R., 1929 Chromosomal variations correlated with geographical distribution in Circotettix verruculatus (Orthoptera). J. Morph. 47:1-36.

1933 The effect of X-rays upon the chromosomes of Circotettix verruculatus (Orthoptera). J. Morph. 55: 265-311.

KING, R. L., 1923 Heteromorphic homologous chromosomes in three species of Pseudotrimerotropis (Orthoptera: Acrididae). J. Morph. 38: 19-63.

Kuzmina, N. E., 1927 On the chromosomes of Beta vnlgaris L. Bull. Appl. Bot., Genet., Pl. Br. 17: $241-252$.

LANCEFIELD, D. E., 1929 A genetic study of crosses of two races or physiological species of Drosophila obscura. Z.I.A.V. 52: 287-317.

Lewitsky, G. A., Melnikov, A. N., and Trtova, N. N., 1932 The cytology of the offspring of the 16-chromosome rye. Bull. Labor. Genetics, Leningrad, 9: 89-96.

NAVASChIN, S., 1912 Sur le dimorphisme nucléaire des cellules somatique de Gallonia candicans. Bull. Acad. Imp. Sci. Petersbourg, VI serie, 4: 373-385.

1927 Zellkerndimorphismus bei Galtonia candicans Des. und einigen verwandten Monokotylen. Ber. deutschen Bot. Ges. 45: 415-428.

Payne, F., 1916 A study of the germ cells of Gryllotalpa borealis and Gryllotalpa vulgaris. J. Morph. 28:

Poulson, D. F., 1934 Times of development of the two races of Drosophila pseudo-obscura. Frol. J. Exp. Zool. 68: 237-245.

SEILER, J., 1917 Zytologische Vererbungsstudien an Schmetterlingen. Sitzungsber. Ges. Naturforsch. Freunde Berlin, Jahrgang 1917: 107-113.

1922a Geschlechtschromosomen Untersuchungen an Psychiden. III. Chromosomenkoppelung bei Solenobia pineti Z. Arch. Zellforsch. 16: 171-216.

1922b Geschlechtschromosomen Untersuchungen an Psychiden. IV. Die Parthenogenese der Psychiden. Z.I.A.V. 31: 1-99.

1925 Zytologische Vererbungsstudien an Schmetterlingen. I. Ergebnisse aus Kreuzungen von Schmetterlingerassen mit verschiedenen Chromosomenzahl. J. Klaus Arch. Vererbungs. Sozialanthrop., Rassenhygiene 1: 63-117.

SoRokIn, H., 1927 Cytological and morphological investigations on gynandromorphic and normal forms of Ranunculus acris L. Genetics 12: 59-83.

Sturtevant, A. H., 1929 The claret mutant type of Drosophila simulans: a study of chromosome elimination and cell lineage. Zeit. wiss. Zool. 135: 323-356.

1931 Known and probable inverted sections of the autosomes of Drosophila melanogaster. Pub. Carnegie Instn. Washington 421: 1-27.

Sweschnikowa, I., 1928 Die Genese des Kerns im Genus Vicia. Verh. V internat. Kongr. Vererbungswissenschaft 2: 1415-1421.

1929 Vicia sativa L. and Vicia cracca L. Bull. Timiriazev Agric. Academy Moscow 4: 1-22.

Thomsen, M., 1927 Studien über die Parthenogenese bei einigen Cocciden und Aleurodiden. Z. Zellf. mik. Anat. 5: 1-116.

Vorsov, D., 1925 Les éléments sexuels de Gryllotalpa vulgaris Latr. Arch. Zool. Exp. Gen. 63 (quoted after DE WINIWARTER 1927).

WILSON, E. B., 1909 Studies on chromosomes. V. The chromosomes of Metapodius. A contribution to the hypothesis of the genetic continuity of chromosomes. J. Exp. Zool. 6: 147205.

DE Winiwarter, H., 1927 Etude du cycle chromosomique chez diverses races de Gryllotalpa gryll. N (L.). Arch. Biol. 37: 515-572. 